Note

\section{Effects of Protein or Polysaccharides on Radiosensitization with $\mathrm{NaCl}$}

\author{
Shigeru Kitayama, Su-Jen Shin Chen \\ and Akira MatsuYama
}

\author{
Radiobiology Laboratory, \\ The Institute of Physical and Chemical Research, \\ Wako-shi, Saitama 351, Japan
}

Received August 10, 1981

It is known that solute in cell suspensions sensitizes or protects the cell from the lethal effect of ionizing radiations. When the cells of $E$. coli capable of repair to DNA damage were irradiated in the presence of alkalihalides, survivals were significantly reduced. ${ }^{1}$ 3) Among the alkali-halides, $\mathrm{Cl}^{-}$requires relatively higher concentrations to sensitize the cells to radiation than $\mathrm{Br}^{-}$or $\mathrm{I}^{-}$. However, the active component for cell inactivation is thought to be $\mathrm{X}_{2}{ }^{-}$in each $(\mathrm{X} ; \mathrm{Cl}, \mathrm{Br}$ or $\mathrm{I})$ which is produced by the following radiochemical reactions.

$$
\begin{gathered}
\mathrm{OH}+\mathrm{X}^{-} \longrightarrow \mathrm{OH}^{-}+\mathrm{X} \\
\mathrm{X}+\mathrm{X}^{-} \longrightarrow \mathrm{X}_{2}^{-}
\end{gathered}
$$

Irrespective of such similarity between these halides, some differences can be seen in their radiosensitizing effect on living organisms. $\mathrm{Cl}^{-}$did not sensitize bacterial spores or fungi to gamma-rays but they were sensitized by $\mathrm{Br}^{-}$or I. $^{-{ }^{3,4)}} \mathrm{NaCl}$ in a phosphate buffer was equally effective at $\mathrm{pH} 5$ or $\mathrm{pH} 7$ while $\mathrm{KBr}$ or $\mathrm{KI}$ was less effective at neutral $\mathrm{pH}$ than at acidic $\mathrm{pH}^{2)} \mathrm{Br}^{-}$and $\mathrm{I}^{-}$sensitized $E$. coli cells more efficiently under anaerobic conditions while no significant oxygen effect was observed in the case of $\mathrm{Cl}^{-2)}$ These differences have been remained to be explained if the active components for the radiosensitization are analogous to each other such as $\mathrm{X}_{2}{ }^{-}$in Eqs. (1) and (2). If the radiosensitization by $\mathrm{NaCl}$ is solely due to $\mathrm{Cl}_{2}{ }^{-}$, it is hard to explain why the cells were sensitized equally at $\mathrm{pH} 5$ or at $\mathrm{pH} 7$ since the yield of $\mathrm{Cl}_{2}{ }^{-}$is much higher at acidic $\mathrm{pH}$ than neutral $\mathrm{pH}^{5,6)}$ Furthermore, if $\mathrm{Cl}_{2}{ }^{-}$is responsible for the radiosensitization, the recovery of colony-forming units by $\mathrm{L}$-valine is incompatible with its low reaction rate constant. $^{8)}$

Of the cells irradiated in the presence of $\mathrm{NaCl}$, recovery from the inhibitory effects on protein, RNA and DNA syntheses were significantly delayed. ${ }^{3)}$ However, no radiosensitization was observed on some mutants of $E$. coli such as polA or recA. ${ }^{3)}$ From these results it is very plausible that a site(s) where very important cellular functions including repair of DNA damage are located is the target for radiosensitization with $\mathrm{Cl}^{-}$.

In this paper it will be reported that the radiosensiti- zation with $\mathrm{NaCl}$ is due to the composite effects induced by radiation and changes of ionic strength during the preparation of cell suspensions or dilution of the samples for plating on broth-agar. It will also be reported that the radiosensitization by $\mathrm{NaCl}$ can be removed by the addition of macromolecular weight compounds to the irradiation buffer.

E. coli $\mathrm{B} / \mathrm{r}$ was used throughout these experiments. Cells were harvested at the exponential phase of growth in $\mathbf{B}_{2}$ broth which contained meat extract $(1 \%)$, peptone $(1 \%)$ and $\mathrm{NaCl}(0.5 \%)$. After washing twice with a potassium phosphate buffer $(0.067 \mathrm{M}, \mathrm{pH} 7)$ the cells were resuspended with the buffer at a concentration less than $10^{8}$ cells/ $\mathrm{ml}$. When they were irradiated in the presence of $\mathrm{NaCl}$, equal volumes of the cell suspension and $1 \mathrm{M} \mathrm{NaCl}$ dissolved in the buffer were mixed. The cells were irradiated with gamma-rays from ${ }^{60} \mathrm{Co}$ under aerobic conditions by air-bubbling during the irradiation. The irradiated cells were spread on the broth-agar to count viable cells after appropriate dilution with the phosphate buffer except where indicated in Table I. Before mixing with cell suspension solutions of the bovine serum albumin, dextran or inulin were dialysed extensively against the phosphate buffer at $4^{\circ} \mathrm{C}$ to remove low molecular weight impurities which might have been incorporated into the cells during irradiation.

As has been seen in the previous papers, ${ }^{3,7)}$ E. coli cells suspended with a phosphate buffer containing $\mathrm{NaCl}$ showed lower colony-forming units-ml than cells in the phosphate buffer without gamma-ray irradiation. This effect might be due to changes of ionic strength by the addition of $\mathrm{NaCl}$ to the cell suspension and by dilution with the phosphate buffer for plating on broth-agar. If the irradiated cells are more sensitive to the change of ionic strength or if the cells exposed to the change of ionic strength are more sensitive to radiation, the mechanism of radiosensitization by $\mathrm{NaCl}$ must be attributed to several factors.

The results in Table I show these composite effects of $\mathrm{NaCl}$. Survival of the cells washed with the phosphate buffer, irradiated in the presence of $\mathrm{NaCl}$ and diluted with the buffer were less than $0.01 \%$ of those irradiated and diluted with the buffer alone. When the cells irradiated in the presence of $\mathrm{NaCl}$ were diluted with a buffer of the same ionic strength, approximately four times higher survivals were observed than the cells treated as described above. A more remarkable effect of the change of $\mathrm{NaCl}$ concentration is that the survivals after irradiation with 20 $\mathrm{krad}$ of gamma-rays in the presence of $\mathrm{NaCl}$ increased 400 fold if there was no change of ionic strength before the cells were spread on broth-agar (Table I, line 4). The cell washed with the buffer containing $\mathrm{NaCl}$ were more sensitive to gamma-rays even if they were irradiated in the absence of $\mathrm{NaCl}$ (Table I, line 5 and 6). From these results the radiosensitization of $E$. coli by $\mathrm{NaCl}$ might be brought about by the composite effects of its presence before, during and after irradiation. 
Table I. EfFects of $\mathrm{NaCl}$ in the Buffers of Washing, Irradiation or Dilution on the CoLONY-Forming ABILITy of E. coli $\mathrm{B} / \mathrm{r}$

\begin{tabular}{|c|c|c|c|c|c|}
\hline \multirow[b]{2}{*}{ Washing } & \multirow{2}{*}{$\begin{array}{c}\text { Buffer } \\
\text { Irradiation }\end{array}$} & \multirow[b]{2}{*}{ Dilution } & \multicolumn{2}{|c|}{ Colony-forming Units $/ \mathrm{ml}$} & \multirow{2}{*}{$\begin{array}{l}\% \text { Survivals } \\
\text { after Irradiation } \\
(\mathrm{B} / \mathrm{A} \times 100)\end{array}$} \\
\hline & & & $\begin{array}{l}\text { Before Irr. } \\
\text { (A) }\end{array}$ & $\begin{array}{l}\text { After Irr. } \\
\text { (B) }\end{array}$ & \\
\hline $\mathrm{PB}^{*}$ & PB & PB & $2.0 \times 10^{7}$ & $5.7 \times 10^{6}$ & 29 \\
\hline PB & $\mathrm{NaCl}^{* *}$ & PB & $1.2 \times 10^{7}$ & $3.0 \times 10^{2}$ & 0.0025 \\
\hline PB & $\mathrm{NaCl}$ & $\mathrm{NaCl}$ & $5.0 \times 10^{6}$ & $4.8 \times 10^{2}$ & 0.01 \\
\hline $\mathrm{NaCl}$ & $\mathrm{NaCl}$ & $\mathrm{NaCl}$ & $8.0 \times 10^{6}$ & $9.5 \times 10^{4}$ & 1.2 \\
\hline $\mathrm{NaCl}$ & PB & PB & $1.0 \times 10^{6}$ & $1.3 \times 10^{5}$ & 13 \\
\hline $\mathrm{NaCl}$ & PB & $\mathrm{NaCl}$ & $1.8 \times 10^{6}$ & $5.7 \times 10^{4}$ & 3.2 \\
\hline PB & PB & $\mathrm{NaCl}$ & $1.6 \times 10^{7}$ & $5.6 \times 10^{6}$ & 35 \\
\hline $\mathrm{NaCl}$ & $\mathrm{NaCl}$ & PB & $8.0 \times 10^{6}$ & $3.2 \times 10^{3}$ & 0.04 \\
\hline
\end{tabular}

* $\mathrm{PB}, 0.067 \mathrm{M}$ potassium phosphate buffer ( $\mathrm{pH} 7)$.

** $\mathrm{NaCl}, 0.5 \mathrm{M} \mathrm{NaCl}$ dissolved in the phosphate buffer. Dose of irradiation was $20 \mathrm{krad}$.

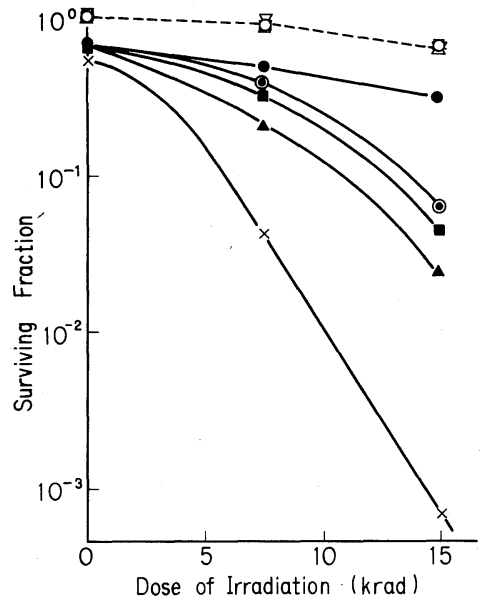

Fig. 1. Effects of Bovine Serum Albumin, Dextran and Inulin on Radiosensitization by $\mathrm{NaCl}$.

Cells washed and resuspended with phosphate buffer (PB) were mixed with or without $1 \mathrm{M} \mathrm{NaCl}$ dissolved with $\mathrm{PB}$. After concentrated solutions of bovine serum albumin, dextran or inulin were dialysed extensively against $\mathrm{PB}$, they were diluted with $\mathrm{PB}$ or $\mathrm{PB}$ containing $\mathrm{NaCl}(\mathrm{NaCl}-$ $\mathrm{PB})$ and were mixed with the cell suspension. Cells irradiated in $\mathrm{PB} \nabla ; \mathrm{NaCl}-\mathrm{PB} \times$; bovine serum albumin $(200 \mu \mathrm{g} / \mathrm{ml}) \bigcirc, \quad \mathrm{NaCl}-\mathrm{PB}$ plus bovine serum albumin $(20 \mu \mathrm{g} / \mathrm{ml}) \odot$; inulin $(20 \mathrm{mg} / \mathrm{ml}) \triangle, \boldsymbol{\Delta}$; dextran $(20 \mathrm{mg} / \mathrm{ml})$ $\square$, $\boldsymbol{\square}$. Open symbols and broken lines, irradiation without $\mathrm{NaCl}$; closed symbols and straight lines, irradiation in the presence of $\mathrm{NaCl}$.

Although the composite effects of $\mathrm{NaCl}$ were observed it is clear that cell survivals were substantially reduced by its presence during irradiation. This radiosensitization disappeared when the cells were irradiated in the buffer containing amino acids. ${ }^{2,3,7)}$ If intracellular $\mathrm{Cl}_{2}{ }^{-}$is responsible for this sensitization, it might be counteracted by cell con- stituents such as amino acids in the cell. The intracellular concentration of total amino acids in an E. coli cell is estimated to be around $10 \mu \mathrm{mol} / 100 \mathrm{mg}$ dry weight of the bacteria ${ }^{9)}$ which is more than $10^{-2} \mathrm{M}$ if the single cell volume is calculated as if it were a rod of $0.5 \mu \times 2 \mu$. This concentration is high enough to suggest that at least one of the targets of $\mathrm{Cl}_{2}{ }^{-}$might be the cell surface and intracellular $\mathrm{Cl}_{2}{ }^{-}$would be effectively counteracted with cell constituents including amino acids. This prediction is supported by the results shown in Fig. 1. The survivors increased substantially when the cells resuspended with the $\mathrm{NaCl}$-buffer were irradiated in the presence of bovine serum albumin $\left(\mathrm{MW}=6.7 \times 10^{4} \mathrm{D}\right)$, dextran $(\mathrm{MW}=$ $\left.1.8 \times 10^{5} \mathrm{D}\right)$ or inulin $\left(\mathrm{MW}=5 \times 10^{3} \mathrm{D}\right)$. Since these compounds were mixed with the cell suspension after extensive dialysis, the contribution of low molecular weight constituents in the samples, if any, could be ruled out as a main reason for their effects. It should be pointed out that bovine serum albumin was the most effective at lower concentrations than the other two polysaccharides. This might be mostly due to the difference between their reaction-rate constant with $\mathrm{Cl}_{2}{ }^{-}$. It can be expected that the rate constant of bovine serum albumin is much higher than those of the polysaccharides because the rate constants of some amino acids, e.g. tyrosine or tryptophane, are the order of $10^{8} \sim 10^{9} \mathrm{M}^{-1} \mathrm{sec}^{-1}$, while the constant of hexose was less than $10^{6} \mathrm{M}^{-1} \mathrm{sec}^{-1}$ (data not shown). From the lack of after-effects of the $\mathrm{NaCl}$-buffer irradiated under aerobic conditions at neutral $\mathrm{pH},{ }^{11)}$ long-lived toxic products such as $\mathrm{Cl}_{2}$ or $\mathrm{HClO}$ may not be responsible for this radiosensitization. On the basis of pulse radiolysis studies of the $\mathrm{NaCl}$ solution, Jayson et al. presented the following mechanism for the production of $\mathrm{Cl}_{2}{ }^{-}$

$$
\begin{gathered}
\mathrm{OH}+\mathrm{Cl}^{-} \rightleftarrows \mathrm{ClOH}^{-} \\
\mathrm{ClOH}^{-}+\mathrm{H}^{+} \rightleftharpoons \mathrm{Cl}+\mathrm{H}_{2} \mathrm{O}
\end{gathered}
$$




$$
\mathrm{Cl}+\mathrm{Cl}^{-} \rightleftharpoons \mathrm{Cl}_{2}^{-}
$$

In the phosphate buffer $(\mathrm{pH} \mathrm{7)}$ used in this study the equilibrium (4) would be over to the left. ${ }^{12)}$ Therefore, a possible involvement of $\mathrm{ClOH}^{-}$in this radiosensitization must be considered at neutral $\mathrm{pH}$. It is very plausible that a kinetic study for the reactivity of solutes with $\mathrm{Cl}_{2}{ }^{-}$by analysing the decay rate of absorption at around $340 \mathrm{~nm}^{6,7,13)}$ might include the absorption due to $\mathrm{ClOH}^{-}$, because $\mathrm{Cl}_{2}{ }^{-}$absorption has a maximum at $340 \mathrm{~nm}$ whereas $\mathrm{ClOH}^{-}$has a maximum at $350 \mathrm{~nm}^{.21}$ Furthermore, the radical reactions might be more complex and competitive with each other in cell suspensions containing $\mathrm{NaCl}$, amino acids, $\mathrm{O}_{2}$ and phosphates which are also reactive with $\mathrm{OH}$ or $\mathrm{H}$ radicals even if phosphates are generally considered to be radiochemically inert. ${ }^{14)}$ Therefore it is very hard to estimate at present how these radicals contribute the radiosensitization of $E$. coli since there are no data on the reaction-rate constants of these radicals with cell constituents measured individually. However, it seems likely that this radiosensitization might be brought about by injury to the cell membrane and not to be the cell wall because replication of phage, $\phi \times 174$, absorbed previously into the host cells, was substantially inhibited by irradiation in the presence of $\mathrm{NaCl}$ (data not shown). Taking into consideration the effects of an ionic strength change and the intricate radical reaction in cell suspension, this radiosensitization might be brought about by the combined effects on the cell membrane and some of which are counteracted by the elimination of $\mathrm{Cl}_{2}{ }^{-}$or $\mathrm{ClOH}^{-}$.

Acknowledgments. We would like to thank Dr. H. Seki and Dr. A. Kira of the Radiation Chemistry Laboratory for their help during the pulse radiolysis studies. We are also grateful to Dr. M. Imamura and Dr.
S. Araifor their helpful discussions. This work was supported in part by a Grant-in-Aid for Scientific Research from the Ministry of Education (No. 401031) and from the Science and Technology Agency of Japan.

\section{REFERENCES}

1) Y. Okazawa, M. Namiki, S. Yamashita and A. Matsuyama, Bull. Agric. Chem. Soc., 24, 235 (1960).

2) A. Matsuyama, M. Namiki and Y. Okazawa, Radiat. Res., 30, 678 (1967).

3) K. Igarashi, T. Hasumai and A. Matsuyama, Agric. Biol. Chem., 42, 989 (1978).

4) M. Simic, E. L. Powers, M. Centilli and M. Cross, Int. J. Radiat. Biol., 25, 43 (1974).

5) A. O. Allen, "The Radiation Chemistry of Water and Aqueous Solutions," D. van Nostrand Company, Inc., Princeton, 1961.

6) M. Anbar and J. K. Thomas, J. Phys. Chem., 68, 3829 (1964).

7) S. S. Chen, S. Arai and A. Matsuyama, Scientific Papers I.P.C.R., 68, 21 (1974).

8) K. Igarashi and A. Matsuyama, Agric. Biol. Chem., 42, 997 (1978).

9) J. Mandelstam, Biochem. J., 69, 103 (1958).

10) G. E. Adams, J. E. Aldrich, R. H. Bisby, R. B. Cundal, J. L. Redpath and R. L. Willson, Radiat. Res., 49, 278 (1972).

11) T. Brustad and E. Wold, Radiat. Res., 66, 215 (1976).

12) G. G. Jayson, B. J. Parsons and A. J. Swallow, J. Chem. Soc. Faraday Trans. I, 69, 1597 (1973).

13) L. K. Patterson, K. M. Bansal, B. Bogan, G. A. Infante, E. J. Fendler and J. H. Fendler, J. Am. Chem. Soc., 94, 9028 (1972).

14) G. Grabner, N. Getoff and F. Schworer, Int. J. Radiat. Biol., 5, 393 (1973). 